УДК 784

DOI: https://doi.org/10.33643/kmus.2019.58.13

Тетяна Круліковська, здобувач кафедри історії музики Львівської національної музичної академії ім. М.В.Лисенка https://orcid.org/0000-0001-5997-158X t.krul@i.ua

Tetiana Krulikovska, Applicant at the Department of Music History, M. V. Lysenko Lviv National Academy of Music, https://orcid.org/0000-0001-5997-158X t.krul@i.ua

\title{
ПОРТРЕТ ВЛАДИСЛАВА ЗАРЕМБИ КРІЗЬ ПРИЗМУ ВОКАЛЬНОЇ ТВОРЧОСТІ
}

У статті здійснено аналіз життєвого й творчого шляху українського композитора польського походження Владислава Заремби в контексті українсько-польських культурних та художніх традицій XIX ст.

Розглянуто тематику й зміст вокальних творів на польські та українські тексти, особливості музичної мови композитора і значення його творів у розвитку української вокальної культури ХІХ ст.

В цілому, окреслено два вектори розвитку вокальної творчості Владислава Заремби - польський та український, які свідчать про виконання високих національних завдань, спрямованих на створення професійної композиторської та виконавської школи в Україні.

Ключові слова: Владислав Заремба, українсько-польські взаємини, життєвий шлях, вокальна творчість, пісні, романси, обробки.

Krulikovska Tetiana. Portrait of Vladyslav Zaremba in the Context of Vocal Creativity. The relevance of the study lies in the comprehensive analysis of the problem of Ukrainian-Polish relations in the context of the cultural and artistic traditions of the XIX century and the research and lifetime periodization of Vladyslav Zaremba, the Ukrainian composer of Polish origin.

In general, the conceptual horizons of the research reflect both theoretical and practical novelty related to the musicological analysis of Vladyslav Zaremba's vocal pieces, found in the musical archives, in close connection with his biography, which has been studied fragmentarily.

The main objective of the study is reproducing through the prism of vocal creativity the life and creative portrait of Vladyslav Zaremba, the Ukrainian composer of Polish origin who lived and worked in Podillia in the XIX century. The 
subject of the research were the themes and content of his lyrics written in Polish and Ukrainian, the features of the composer's musical language and the significance of his works in the development of the Ukrainian vocal culture of the XIX century.

The purpose of the article subjects the following research objectives: 1) to analyze the lyrics of the romances written by Polish composers; 2) to analyze the vocal works on Taras Shevchenko's poems «Kobzar by Taras Shevchenko» and the adaptations of popular songs; 3) to outline the aesthetic peculiarities and pedagogical tasks of the vocal collection «The songbook for our children» («Spiewnik dlia naszych dziatek»).

The study methodology is based on the concept of the complex arts research and provides for the use of analytical, dialectical, comparative and socio-cultural approaches.

Conclusions. The results of the study are the addition of some certain facts to the biographical portrait of the composer and the attempt to periodize V. Zaremba's life and creative career in close connection with his vocal creativity.

The article deals with three main periods: the early period, Zhytomyr period (1856-1862) and Kyiv period (1862-1902).

The work reveals the features of the romances on the lyrics of Polish songwriters («Jam ci oddal serce mоје», «Ріоsnка i Mazurek», «Lirnik»), the songs and romances on Taras Shevchenko's poems «Kobzar by Taras Shevchenko», as well as the adaptations of popular songs. It considers the vocal collection of pedagogical character «The songbook for our children» («Spiewnik dlia naszych dziatek»), which contains a close connection with the traditions of bringing up children in Polish families that have high religious values and respect to the national heritage.

In general, the article outlines two vectors in the development of Vladyslav Zaremba's vocal creativity - Polish and Ukrainian, which testify to the fulfillment of the high national tasks aimed at creating of professional composing and performing school in Ukraine.

The chronology of writing the musical works by V. Zaremba, searching and collecting author's sheet music editions with the purpose of the entire reproduction of his creative heritage require further researching.

Keywords: Vladyslav Zaremba, Ukrainian-Polish relations, lifetime, vocal creativity, songs, romances, adaptations.

Круликовская Татьяна. Портрет Владислава Зарембы в контексте вокального творчества. Актуальность темы состоит в комплексном анализе проблемы украинско-польских взаимоотношений в контексте культурных и художественных традиций XIX ст., исследовании 
и периодизации жизненного пути украинского композитора польского происхождения Владислава Зарембы.

В целом, концептуальные горизонты исследования отражают как теоретическую, так и практическую новизну, связанную с музыковедческим анализом найденных в нотных архивах вокальных произведений Владислава Зарембы, в тесной связи со страницами его биографии, которая на сегодня изучена фрагментарно.

Цель статьи - воспроизведение жизненного и творческого портрета украинского композитора польского происхождения Владислава Зарембы, который жил и работал на Подолье в XIX в., сквозь призму его вокального творчества. Предметом исследования стали: тематика и содержание произведений, особенности музыкального языка композитора и значение произведений в развитии украинской вокальной культуры XIX в.

Методологическая база основывается на концепции комплексного искусствоведческого исследования и предполагает применение аналитического, диалектического, компаративного и социокультурного подходов.

Bbыводы. В результате исследования были добавлены отдельные факты к биографическому портрету композитора и предпринята попытка периодизации жизненного и творческого пути В. И. Зарембы в тесной связи с его вокальным творчеством. Определены три основных периода: ранний период, Житомирский (1856-1862 годы) и Киевский (1862-1902 годы).

В работе раскрыты особенности романсов на тексты польских композиторов («Jam ci oddal serce moje», «Piosnкa u Mazurek», «Lirnik»), песен и романсов на слова Тараса Шевченка «Кобзарь Тараса Шевченка», а также обработок популярных песен.

Рассмотрены вокальный сборник педагогического характера «Песенник для наших детей» («Spiewnik dia naszych dziatek»), который имеет тесную связь с традициями воспитания детей в польских семьях, проникнутых высокой религиозностью и уважением к национальным ценностям.

В целом, обозначены два вектора развития вокального творчества Владислава Зарембы - польский и украинский, свидетельствующие о выполнении высоких национальных задач, направленных на создание профессиональной композиторской и исполнительской школы в Украине.

Требует дальнейшего исследования хронология написания музыкальных произведений В. Зарембы, поиск и сбор нотных изданий автора для целостного воспроизведения его творческого наследия.

Ключевые слова: Владислав Заремба, украинско-польские отношения, жизненный путь, вокальное творчество, песни, романсы, обработки. 
Українсько-польські культурні й мистецькі традиції склали історичні передумови для глибокого взаємного проникнення елементів двох національних культур та світоглядних позицій у творчість польських композиторів, що жили й працювали на теренах України протягом XIX ст.

В українському музикознавстві окреслилась проблема цілісного осмислення феномену української композиторської школи в творчому доробку польських композиторів українського походження.

У 2018 виповнилось 185 років від дня народження українського композитора польського походження Владислава Івановича Заремби, життєвий і творчий шлях якого потребує грунтовного дослідження.

Актуальність теми полягає в комплексному аналізі проблеми українсько-польських взаємин у контексті культурних і художніх традицій XIX ст. і дослідженні й періодизації життєвого шляху українського композитора польського походження Владислава Заремби.

У цілому, концептуальні обрії дослідження відображають як теоретичну, так і практичну новизну, пов'язану з музикознавчим аналізом віднайдених у нотних архівах вокальних творів Владислава Заремби в тісному зв’язку зі сторінками його біографії, яка на сьогодні вивчена фрагментарно.

Mema cmammi - відтворити життєвий і творчий портрет українського композитора польського походження Владислава Заремби, що жив i працював на Поділлі у XIX ст., через призму його вокальної творчості.

Мета статті підпорядковує такі завдання дослідження: 1) здійснити аналіз романсів на тексти польських композиторів; 2) проаналізувати вокальні твори на слова Тараса Шевченка «Кобзар Тараса Шевченка», обробки популярних пісень; 3) окреслити естетичні особливості й педагогічні завдання вокальної збірки «Пісенник для наших дітей» («Spiewnik dia naszych dziatek»).

Методологічна база грунтується на концепції комплексного мистецтвознавчого дослідження та передбачає застосування аналітичного, діалектичного, компаративного та соціокультурного підходів.

Вивченням професійної подільської музичної культури в контексті загальнонаціонального процесу займались у різні історичні періоди М. Дремлюга, Л. Кияновська, М. Печенюк, А. Сваричевський, В. Прокопчук, М. Антошко, Т. Вільчинська, Т. Прокопчук, В. Прокопчук, О. Пажимський, О. Шалак, О. Гармель, Ф. Ернст, Д. Щербаківський, В. Іванов, О. Різник, А. Житкевич, Н. Руденко та ін. Ця тема привертала увагу подільських краєзнавців і музикознавців, серед яких слід назвати
А. Свидницького,
Р. Римар,
В. Святелика,
В. Циганюка,
Я. Кушку,
О. Пажимського, М. Ярову, П. Слободянюка, Ю. Портного. 
Виклад основного матеріалу. Енциклопедичні джерела містять досить стислу біографію представника польського дворянського роду XIX ст. - подільського композитора Владислава Заремби. Здебільшого джерела містять основні дати життя композитора й перелік його найвідоміших творів.

Народився Владислав Заремба 15 червня 1833 року в м. Дунаївці на Поділлі в збіднілій шляхетській сім’ї.

В. С. Прокопчук чи не єдиний, хто згадує у своїй статті про батьків композитора: «Батьки цінували музичне мистецтво, вдома завжди звучали українські і польські пісні. А Владислав переймався їх красою, формуючи багатий світ уяви, тонке сприйняття краси мелодій» [10, с. 562].

1846 року В. Заремба з батьками переїхав до губернського міста Кам'янець-Подільського. Його творчий шлях розпочався під орудою талановитого педагога, композитора й етнографа-фольклориста Антона Коціпінського (1816-1866), який сприяв формуванню музичного світогляду, подальших життєвих і творчих уподобань молодого Владислава Заремби.

Скрутні умови, в які потрапила й польська громада: русифікація України та інших окраїн імперії, активна дискримінаційна політика Царського уряду стосовно національних меншин - призвели до відкритого й нелегального опору цій політиці, до розвитку культурно-просвітницького руху в його середовищі для збереження національного самовираження.

Кам'янець-Подільський став одним 3 осередків польського культурно-просвітницького руху на Поділлі. Зокрема, у власному будинку А. Коціпінський «...щонеділі влаштовує домашні концерти з виконанням українських і польських пісень, що користувалися успіхом в опозиційно настроєного студентства» [5, с. 384].

1849 року, тобто невдовзі після «весни народів», А. Коціпінського було вислано з Росії за знайдені у нього заборонені царською цензурою книжки, вірші й пісні, серед яких - твори польських і українських поетів Томаша Падури, Юліуша Словацького, Юзефа Крашевського.

Після закінчення навчання Владислав Заремба на деякий час виїжджав до Польщі [8, с. 52]. 25 вересня 1854 року поліцмейстер рапортував Подільському губернаторові: «Владислав Заремба, 22 років, приїхав давати уроки гри на фортепіано та в пошуках посади органіста. Проживає в місті з 8 вересня 1854 року. Житло на перших порах обладнав у Кармелітському монастирі. Працював органістом у костьолі (3 1855 року). Мав учнів фортепіанної гри» [10, с. 562]. 3 юнацьких років Владислав Заремба, як і його вчитель А. Коціпінський, збирав і записував народні пісні [8, с. 52]. 
За невизначених обставин, можливо, через пропаганду польських національних ідей, можливо, і написання творів забороненими польською та українською мовами, за В. Зарембою було встановлено таємний поліцейський нагляд. Це спонукало молодого композитора 1856 року переїхати до Житомира, де розпочалась його активна музично-педагогічна й композиторська діяльність: він давав уроки фортепіанної гри, виступав у концертах як соліст і акомпаніатор, учасник камерних ансамблів та згодом отримав запрошення до Київського інституту шляхетних дівчат на викладацьку посаду.

Цікаво, що саме 1855 року до Києва 3 Відня повернувся й А. Коціпінський, який відкрив у столиці на Хрещатику музичний магазин i музичну книгарню з філією в Житомирі, які стали осередками музичного життя. Можна зробити припущення, що впливовий педагог, активний громадський діяч А. Коціпінський міг далі спілкуватись зі своїм учнем, будучи в центрі культурних і політичних подій того часу.

У Житомирі 30 травня 1861 року народився син Владислава Заремби Сигизмунд, майбутній композитор. У радіопрограмі Житомирського радіо «Музичні шедеври», присвяченій 155-й річниці від дня народження Сигизмунда Заремби, музикознавець Ірина Копоть говорить про те, що Владислав Заремба був пов'язаний із Житомирським театром, а також працював у приватних навчальних закладах.

Київський період (з 1862 року) становить розквіт педагогічної та композиторської діяльності В.Заремби. Цей час відзначено загальним піднесенням національно-визвольних настроїв поляків та їхнього найближчого оточення, пожвавленням просвітницького руху в студентських колах i товариствах, поглибленням національної ідентичності, що пов’язано з подіями Січневого повстання 1863-1864 рр. «На фортепіано все частіше звучали патріотичні мелодії, все частіше можна було почути завзяту мазурку, патріотичні марші та пісні, побачити паничів в чамарках та високих чоботах» [9, с. 588].

У Києві В. Заремба працював на посаді викладача по класу фортепіано i хорового співу в Інституті благородних дівчат, Левашівському інституті, приватних пансіонах.

В умовах репресивної політики пансіони змогли уникнути суцільного контролю, стали після домашнього навчання єдиним місцем, де можна було вивчити польську мову, ознайомитись із творами класиків польської літератури, отримати освіту та оминути російську школу. 
Владислав Заремба - автор творів для дітей, серед яких - вокальний «Пісенник для наших дітей» («Spiewnik dia naszych dziatek») i фортепіанний «Маленький Падеревський» («Maty Paderewsky»).

Збірник «Пісенник для наших дітей», який було видано видавництвом Л. Ідзіковського (Варшава), належить до творів педагогічного характеру й відповідає традиціям виховання дітей у польських сім'ях, пройнятих високою релігійністю та повагою до національних традицій.

У досліджуваний історичний період Україна не мала національної системи освіти, яка б забезпечувала поступове культурне зростання нації. «Русифікаційний наступ не дозволяв демонструвати свою національну ідентичність публічно, що привело до переходу функцій збереження національного в приватну сферу - в родину», зазначає О. Ніколаєнко. Саме 3 родини велось виховання дітей, і католицизм був невід'ємною частиною національного характеру поляків [6].

У часи, коли кожен приклад в підручниках, який можна було трактувати як польське національне виховання, переслідувався владою, створення цієї збірки було надто сміливим кроком, спрямованим на виховання та збереження національних традицій.

Важливе місце у збірнику займають пісні релігійного змісту, які містять щоденні молитви: «Modlitwa dziecka» («Дитяча молитва»), «Do Boga» («До Бога»), «Wieczorny pacierz» («Вечірня молитва»), а також пісні на найважливіші періоди церковного року: Різдво Христове - «Aniot pasterzom mówil» («Ангел сказав пастушкам»), «Bóg się rodzi» («Бог роджений»); та Великдень - «W żłobie leżę» («В жалобі лежу»), «Wesoly nam dziś dzień nastal» («Веселий нам цей день настав»).

Різноманітний світ дитинства автор передає: через змалювання картин природи - «Kiedy ranne wstaja zorze» («Коли рання встає зоря»), «Pole» («Поле»), «Gwiazda» («Зірка»), «Zima» («Зима»); зображення світу тварин і птахів - «Kogutek» («Півник»), «Ptaszek» («Пташка»), «Lata ptaszek po ulicy» («Літа пташок по вулиці»), «Piosenka o wilku» («Пісенька про вовка»), «Siedzisobie zajac pod miedzą («Сидів собі зайчик під балком»). Пісні «Przechadzka» («Прогулянка»), «Polowanie» («Полювання»), «Dalej! Dalej!» («Далі! Далі!»), «Wesoty Janek» («Веселий Янек»), «Krakoviak» («Краков'як») пов’язані 3 емоційно-рухливою активністю дитини. Не оминає автор і соціальної тематики, яка розкривається 3 урахуванням дитячого рівня сприйняття у піснях «Panieoneczka» («Паняночка»), «Jałmużna ubogiej dziecięca» («Милостиня для дітей»), «Pieśń ubogiej dziewczynki» («Пісня бідної дівчинки»). 
Цілком імовірно, що збірка «Spiewnik dia naszych dziatek» була укладена з метою приватної педагогічної практики для дітей із заможних польських родин, де музика відігравала важливу роль. Не виключено, що на окремих творах цієї збірки міг виховуватись і син композиторамайбутній композитор Сигизмунд, для якого батько був першим учителем музики. Однак авторська присвята Владислава Заремби «Моїм онукам» дає точну інформацію про те, що збірка є підсумком педагогічної праці автора й, імовірно, упорядкована в останній період його життя.

Київський період також містить сольні вокальні та фортепіанні твори, зокрема й для домашнього музикування, обробки популярних пісень.

Переважну більшість розглянутих творів було опубліковано у видавництві Леона Ідзіковського в Києві, однак хронологія їх написання потребує дослідження. Відомо, що фірму було засновано в 1858-1859 роках Леоном Вікентійовичем Ідзіковським, і пропрацювала вона до 1919 року.

3 ініціативи Г. Ідзіковської 1873 року книгарня почала друкувати «Нотне видання композиторів» («Wydawnictwo Nutowe Kompozytorów»), публікуючи, передусім, твори місцевих авторів. Цим було започатковано відділ нот [1, с. 393]. Таким чином, Київський період творчості В. Заремби співпадає 3 періодом діяльності найвпливовішої на той час польської музичної видавничої фірми в Україні й Російській імперії, однак це не виключає написання виданих творів у більш ранній період.

Серед віднайдених в архівах творів В. Заремби на слова польських авторів є такі, що належать до сфери інтимної лірики: «Jam ci oddal serce moje» на слова Андрія Яновича та «Piosnка $i$ Mazurek» на слова Францішека Дабровського. Романси, які відтворюють світ внутрішніх переживань i роздумів закоханих чоловіків, можна віднести до творів салонного чи домашнього музикування. Їхньою жанровою основою $\epsilon$ граційний вальс і гордовита мазурка. Форма творів куплетна, музична мова відзначається нескладним тональним планом і прозорістю фактури.

Іншим за змістом є «Lirnik» на слова сучасника композитора Антона Станіславського (1817-1883). Твір має присвяту Юзефу Ігнацію Крашевському (1812-1887) на честь 50-річного ювілею, 3 чого можна зробити припущення про дату написання романсу - 1862 рік. 1856 року Крашевський був призначений директором Житомирського театру. Імовірно, Владислав Заремба був обізнаний 3 його творчістю через А. Коціпінського, а можливо, знав його та мав творчу співпрацю, оскільки пізніше також працював у Житомирському театрі.

Відомий польський письменник, публіцист, видавець, польський та український громадський і політичний діяч Юзеф Ігнацій Крашевський 
зазнав переслідувань, арештів, еміграції, тому його життя порівнюється 3 непростою долею лірника - народного співця. Цей романс містить роздуми про невтішну долю митця, його призначення в житті та звернення до Бога в скрутну хвилину.

Романс розпочинається вступом, який налаштовує на зміст твору. Повільний темп, неширокий діапазон мелодії з рисами декламаційності наближають твір до епічних жанрів. Форма твору двочастинна. Перша частина (тональність $h$-moll) - філософський роздум про скарб - стару ліру, пісні та злу долю митця. Друга частина твору контрастує тонально $(H-d u r)$ - це згадка співця про світлі миттєвості життя й молитва до Бога. Співставлення одноіменного міноро-мажору, використання гармонічних ладів (зб. 2), заокруглені завершення фраз у мелодії, мелодизована фактура фортепіано влучно втілюють зміст поетичного тексту, дають змогу зануритись у складний психологічний стан героя.

Період романтизму окреслив зацікавленість польських митців не лише українською історією, фольклором, але й українською поезією, зокрема, творчістю видатного поета XIX ст. Тараса Шевченка. Не залишився осторонь цієї тенденції й В. Заремба, автор збірки «Кобзар Тараса Шевченка» (видання Леона Ідзіковського в Києві, 1889 рік). Вокальна збірка, яка складається 3 двох серій по 15 творів у кожному зшитку, відіграла значну роль у розвитку жанру українського романсу та становленні української Шевченкіани XIX ст ${ }^{1}$.

Цей час відзначився переслідуванням з боку уряду української мови та культури, що згубно відбивалося на розвитку освіти, літератури й мистецтва. 1863 року міністром внутрішніх справ Петром Валуєвим було видано таємний циркуляр про заборону публікацій українською мовою, особливо педагогічних. Згідно з Емським актом, з 1876 року заборонялося ввезення до імперії без окремого на те дозволу Головного управління будь-яких книг і брошур, що видавалися за кордоном українською мовою, не дозволялися різні сценічні вистави та читання, а також друкування текстів до нот цією мовою [1, с. 109].

Зміст переважної більшості вокальних композицій, у яких В. Заремба спирається на вірші Т. Шевченка, пов'язаний із типово народними характерами, а також відзначається проникненням у складний та багатий внутрішній світ своїх героїв.

\footnotetext{
${ }^{1}$ У музикознавчих джерелах лише згадується про існування цієї збірки у творчому доробку композитора та зазначаються назви окремих пісень, як от: «I багата я, i вродлива я...», «На улиці невесело...», «Така iï доля...», «Утоптала стежечку...», «Чого ти ходиш на могилу?», «Якби мені, мамо, намисто», «Якби мені черевики» [13].
} 
Знайшли відгук у вокальному доробку В. Заремби теми сирітства, самотності, чужини, кохання, типово романтичні мотиви козацької волі, настрої журби й туги, які становлять образно-поетичний зміст віршів Т. Шевченка.

За образним змістом романси можна поділити на декілька груп:

- твори філософського змісту, роздуми про тяжку долю: «Минають дні», «Ой люлі, люлі», «І тут, і всюди - скрізь погано»;

- твори про сирітство, самотність: «Ой, умер старий батько», «Сонце заходить», «Ой одна я, одна», «Закувала зозуленька»;

- твори про козака, загубленого на чужині, про козацьку волю: «Тече вода в синє море», «Над Дніпровою сагою», «Не женися на багатій»;

- твори про соціальну несправедливість і тяжку жіночу долю: «Не журюся я, не спиться», «Не тополю високую», «На вулиці не весело», «Нащо мені чорні брови», «Якби мені черевики», «Якби мені, мамо, намисто», «І багата я, і вродлива я».

Завершує збірку «Заповіт», який став своєрідним гімном визвольної боротьби українського народу, втіленням мрії про його світле майбутнє. Символічно, що в останньому романсі як підсумок зазвучали героїчні прагнення до визволення народу, розбудови нового вільного суспільства.

Очевидно, зазначені твори було написано для домашнього музикування, яке широко практикувалось у культурі й мистецькому побуті XIX ст. Згодом пісні та романси композитора завдяки своїй інтонаційній співучості, природній мелодичності, що кореспондують з народним типом викладу, увійшли до репертуару багатьох видатних виконавців. Відомо, що солоспіви «Вітре буйний, вітре буйний» та «Над Дніпровою сагою» Владислава Заремби увійшли до камерно-вокального репертуару видатної співачки світового рівня Соломії Крушельницької [4, с. 43].

Вокальна творчість В. Заремби на слова Т. Шевченка синтезувала надбання європейської школи з окремими елементами національної. Вона цілком відповідає втіленню естетики романтизму, окреслює певні напрямки, які будуть в подальшому розвинені М. Лисенком i його послідовниками, а відтак - становить важливий етап у формуванні української професійної композиторської школи та претендує на заслужене місце у становленні вокальної Шевченкіани XIX ст. ${ }^{1}$

Але чи не найбільш відомим став композитор В. Заремба в широких колах завдяки обробкам пісень для голосу й фортепіано, серед яких: «Нi, мамо, не можна нелюба любить» (сл. Є. Гребінки, музика народна), «Стоїть гора високая» (сл. Л. Глібова, музика народна), «Сонце низенько, вечір близенько» (романс із опери «Вій» М. Кропивницького, 
сл. С. Писаревського), «Дивлюсь я на небо» (сл. М. Петренка, муз. Л. Александрової ), «Повій, вітре, на Вкраїну» (сл. С. Руданського, муз. Л. Александрової), «Де ти бродиш, моя доле» (сл. С. Писаревського), «Така iі доля» (сл. Т. Шевченка) та ін., які донині користуються популярністю. У жанрі вокальної обробки В. Заремба дав нове життя тим мелодіям, які були популярні в його середовищі. Поклавши їх на ноти й гармонізувавши, він сприяв їх популяризації в аматорських колах та професійному середовищі.

В. І. Заремба відійшов у вічність у жовтні 1902 року, похований у Києві на Байковому кладовищі. Енциклопедичні джерела містять інформацію про дату смерті композитора - 11 жовтня. Однак виникає розбіжність щодо дати смерті композитора 3 огляду на джерело «Театр и искусство», оскільки 27 жовтня 1902 року в газеті було розміщено некролог: «В Киеве 19 октября скончался старейший композитор-педагог Владислав Заремба. Покойный родился 15 июня 1833 г. С 1862 года жил в Киеве в качестве преподавателя игры на фортепиано при Левашевском пансионе и др. Заремба написал больше 30 песен на слова Шевченко (Музыка до Кобзаря), польские романсы и песни и фортепианные переложения малороссийских народных песен, а также составил “Сборник песен польских композиторов”» [14].

Висновки. У статті проаналізовано історичні події ХІХ ст., які вплинули на творчість композитора, іiі зміст та жанрові спрямування; окреслено роль педагога, композитора й етнографа-фольклориста Антона Коціпінського, який сприяв формуванню музичного світогляду, подальших життєвих та творчих уподобань молодого Владислава Заремби; додано окремі деталі до біографічного портрету композитора та здійснено спробу періодизації життєвого й творчого шляху В. І. Заремби в тісному зв'язку 3 його вокальною творчістю та означено:

- ранній період: роки навчання в Кам’янці-Подільському, служба на посаді органіста, початок педагогічної роботи, збір народних пісень;

- Житомирський період (1856-1862 роки) - активна музичнопедагогічна й композиторська діяльність, робота в Житомирському театрі;

- Київський період (1862-1902 роки) - розквіт композиторської діяльності: створення вокальних мініатюр на польські тексти, збірки пісень і романсів «Кобзар Тараса Шевченка», оригінальних фортепіанних творів та обробок народних пісень для фортепіано, обробок популярних народних i авторських пісень; педагогічна діяльність на посаді викладача по класу фортепіано й хорового співу в Інституті благородних дівчат, Левашівському інституті, приватних пансіонах і написання педагогічних праць для дітей вокальної збірки «Пісенник для наших дітей» («Spiewnik dia naszych dziatek») і фортепіанної збірки «Маленький Падеревський» («Maty Paderewsky»). 
Унаслідок здійсненого аналізу констатуємо, що творчий доробок В. Заремби, зокрема його вокальна спадщина, демонструє два вектори в розвитку його творчості - польський та український, які мали спільну мету-зацікавлення національними традиціями обох народів та їх збереження, прагнення до національної свободи в складних умовах політичних та ідеологічних конфліктів, розвиток культурних надбань, формування музичного професіоналізму, створення професійної композиторської та виконавської школи в Україні.

1. Грищенко Ю. В., Котирло Т. В., Філіпчук Н. О. Розвиток професійного досвіду педагогів-музикантів у вищих навчальних закладах України (XVIII-XX ст.) : монографія / за ред. Г. І. Сотської, С. В. Коновець. Київ, 2016. 238 с.

2. Гуль О. М. Діяльність фірми «Леон Ідзіковський» (книготоргівля, книго- та нотовидання, приватна публічна бібліотека)// Рукописна та книжкова спадщина України. 2016. Вип. 20. С. 391-400.

3. Кияновська Л. Антон Коціпінський: репрезентант польської культури в українській музиці // Наукові збірки Львівської національної музичної академії ім. М. В. Лисенка. Вип. 27. Львів, 2013. С. 26-37.

4. Комаревич І. Л. Поезія Тараса Шевченка у камерно-вокальному репертуарі Соломії Крушельницької // Психологія і суспільство : теоретико-методологічний соціогуманітарний часопис. 2014. Спецвипуск. С. 42-44. URL: http://dspace.tneu.edu.ua/bitstream/316497/15530/1/42-44.pdf (дата звернення: 15.11.2018).

5. Музыкальная энциклопедия в 6 томах / под ред. Ю. В. Келдыша. Москва: Советская энциклопедия. 1973-1982. Том 3: Коципинский А. С. 384.

6. Ніколаєнко О. Твердиня польськості: національна місія жінки у польській родині Наддніпрянщини на межі XIX-XX ст.// Україна модерна : міжнародний інтелектуальний часопис. 14.05.2016. URL: http://uamoderna.com/md/nikolaenkopolish-women (дата звернення: 11.11.2018).

7. Озимовська А. Історіографія польських музикантів-педагогів на Поділлі// Педагогічний дискурс. 2013. Вип. 15. С. 489-496.

8. Печенюк М. А. Музично-творча діяльність мистців Поділля - сучасників Ференца Ліста // Актуальні питання мистецької педагогіки : зб. наук. праць міжнар. наук.практ. конф. «Ференц Ліст і Україна. Ференц Ліст і Поділля. Музично-педагогічний аспект» (22-23 вересня 2011 р., м. Хмельницький)/ гол. ред. .М.Шоробура. Хмельницький : ХГПА, 2011. Вип. 1. С. 51-53.

9. Познанський Б. Воспоминания о польском восстании в Украине 1863 года (окончание) // Киевская старина: ежемесячный исторический журнал. 1885. № 12. С. 571-611.

10. Прокопчук В. С. Владислав Заремба - український i польський композитор // Поляки на Хмельниччині: погляд крізь віки: збірник наукових праць за матеріалами міжнародної наукової конференції (м. Хмельницький, 23-24 червня 1999 року). Хмельницький: Поділля, 1999. С. 562.

11. Прокопчук В. С. Подільські сторінки в біографії і творчості Тараса Шевченка // Українська біографістика. 2014. Вип. 11. С. 160-170.

12. Риман Г. Музыкальный словарь / пер. с 5-го нем. изд., доп. рус. отд. Москва; Лейпциг, 1896. 1660 с. 
13. Старенький I. Кам’янецький піаніст // Кам'янецький часопис «Ключ». 30.10.2015. URL: http://klych.com.ua/articles/history/kamyanetskyy-pianist/ (дата звернення: 03.10.2018).

14. Театр и искусство. Киев, 1902. № 44.803 с.

15. Ярцун Ю. О. Повсякденне життя шляхти Київської губернії (кін. XVIII - 60-ті pp. XIX ст.) : дис. ... канд. історичних наук (доктора філософії) : 07.00 .01 «сторія України» (032 - Історія та археологія) / Уманський держ. пед. університет ім. Павла Тичини. Умань, 2018. 234 с.

\section{References}

1. Grishchenko, Y., Kotyrlo, T., Filipchuk, N. (2016). Development of professional experience of teachers-musicians in higher educational establishments of Ukraine (XVIII-XX centuries). G. Sotska, S. Konovets (Eds.). Kyiv [in Ukrainian].

2. Gul, O. (2016). The activities of the firm «Leon Idzikovsky» (book trade, book and notebooks, private public library). Rukopysna ta knyzhkova spadshchyna Ukrainy, 20, pp. 391-400 [in Ukrainian].

3. Kiyanovskaya, L. (2013). Anton Kostipinsky: Representative of Polish culture in Ukrainian music. Naukovi Zbirky Lvivskoi Natsionalnoi Muzychnoi Akademii im. M. V. Lysenka, 27, pp. 26-37 [in Ukrainian].

4. Komarevich, I. (2014). Poetry of Taras Shevchenko in the chamber vocal repertoire of Solomia Krushelnytska [online]. Available at: http://dspace.tneu.edu.ua/bitstream/316497/15530/1/42-44.pdf [Accessed 15 November 2018] [in Ukrainian].

5. Music Encyclopedia in 6 volumes (1973-1982) / ed. Yu. V. Keldysh. Moscow: Soviet Encyclopedia, Volume 3: Cotsipinsky A., p. 384 [in Russian].

6. Nikolayenko, O. (2016). The solidity of polity: the national mission of a woman in the Polish family of the Dnieper at the turn of the nineteenth and twentieth centuries [online]. Available at: http://uamoderna.com/md/nikolaenko-polish-women [Accessed 15 November 2018] [in Ukrainian].

7. Ozimovskaya, A. (2013). Historiography of Polish musicians-teachers in Podillia. Pedahohichnyi Dyskurs, 15, pp. 489-496 [in Ukrainian].

8. Pechenyuk, M. (2011). Music and creative activity of the artists of Podillia contemporaries of Ferenc Liszt. Aktualni pytannya mystetskoyi pedahohiky. I. M. Shorobura (Eds.). Khmelnytsky: HGPA, 1, pp. 51-53 [in Ukrainian].

9. Poznanskyy, B. (1885). Recollections of the Polish uprising in Ukraine in 1863 (ending). Kyevskaya staryna, 12, pp. 571-611 [in Russian].

10. Prokopchuk, V. (1999).Vladislav Zaremba - Ukrainian and Polish composer. In: Polyaky na Khmelnychchyni: pohlyad kriz viky. Khmelnytsky: Podillya, p. 562 [in Ukrainian].

11. Prokopchuk, V. (2014). Podilsky pages in the biography and works of Taras Shevchenko. Ukrayinska biohrafistyka, 11, pp. 160-170 [in Ukrainian].

12. Riman, G. (1896). Musical Dictionary. Trans. from the 5th German edition. Moscow; Leipzig [in Russian].

13. Starenkyy, I. (2015). Kamyanets pianist. Kamyanets magazine «Klyuch», [online] 30.10.2015. Available at: http://klych.com.ua/articles/history/kamyanetskyy-pianist/ [Accessed 3 October 2018] [in Ukrainian].

14. Teatr $i$ iskusstvo (1902), 44 [in Russian].

15. Yartsun, Y. (2018). The daily life of the gentry of the Kyiv province (the end of the XVIII - 60th years of the XIX century). PhD thesis. Uman: Pavlo Tychyna Uman State Pedagogical University [in Ukrainian]. 